DOI: http://dx.doi.org/10.18524/2307-4663.2021.2(52).239676

УДК604.4:615.281.9:663.051

\author{
Н.Ю. Васильєва, Г.В. Ямборко, А.Г. Мерліч, \\ І.В. Страшнова, І.П. Метеліцина \\ Одеський національний університет імені І.І. Мечникова, \\ вул. Дворянська, 2, Одеса, 65082, Україна, \\ e-mail: tatkamic@onu.edu.ua

\section{ВПЛИВ БАКТЕРІОЦИНУ ENTEROCOCCUS ITALICUS ONU 547 ТА ЕФІРНИХ ОЛІЙ НА РІСТ УМОВНО-ПАТОГЕННИХ МІКРООРГАНІЗМІВ}

\begin{abstract}
Мета. Оичінити вплив бактеріоцину Enterococcus italicus ONU 547 ma ефірних олій окремо та в комбінації до тест-итамів умовно-патогенних мікроорганізмів. Методи. Антагоністичну активність бактеріоцину та ефірних олій визначали за показником оптичної щільності суспензї бактеpiŭ тест-итамів (Salmonella enterica NCTC 6017, Escherichia coli ATCC 25922, Pseudomonas aeruginosa ATCC 27853, Pseudomonas putida KT 2440, Enterococcus faecalis ATCC 29212, Klebsiella pneumoniae ATCC 10031, Staphylococcus aureus ATCC 25923). Індекс фракційної пригнічувальної конизентрації (FIC) розраховували иляхом складання значень FIC бактеріоцину E. italicus ONU 547 і дослідних ефірних олій. Результати. Максимальний антимікробний ефект спричиняли ефірні олї̈ Анісу лікарського (Anisum officinalisa) та Меліси лікарської (Melissa officinalis), які пригнічували ріст тест-итамів більше ніж на 50,0\%. При використанні бактеріоичну Enterococcus italicus ONU 547 пригнічення життєздатності індикаторних штамів не перевищувало 30,0\%. Дослідні комбінації ефірних олій та бактеріоцину спричиняли 4 типи наслідків: ефект синергії; адитивний ефект; антагоністичний ефект; інтерактивний ефект (відсутність ефекту взаємодіï). У більшості випадків сукупна дія бактеріоцину та ефірних олій спричиняла адитивний ефект. Висновки. Це дослідження продемонструвало потенціал використання різних комбінацій природних протимікробних сполук. Отримані результати надають підстави для подальшої розробки та оптимізаџї комбінаџій ефірних олій і пробіотичних штамів мікроорганізмів з метою використання у харчових та фармацевтичних біотехнологіях.
\end{abstract}

Ключові слова: антимікробна активність, ефірні олії, бактеріочин

Сучасні біотехнологічні виробництва стикаються з необхідністю розробки нових підходів при виготовленні продуктів харчування для людини або харчових добавок у тваринництві, які стануть альтернативою антибіотиків.

Використання бактеріальних антимікробних пептидів (бактеріоцинів) як натуральних харчових консервантів одне 3 таких рішень. Бактеріоцини відрізняються від класичних антибіотиків трьома основними властивостями: синтез бактеріоцинів відбувається на рибосомах, бактеріоцини мають специфічний спектр дії, кожен бактеріоцин має свій власний спеціалізований імун-

(C) Н.Ю. Васильєва, Г.В. Ямборко, А.Г. Мерліч, І.В. Страшнова, І.П. Метеліцина, 2021 
ний білок [5]. Серед досліджених бактеріоцинів значну нішу займають ентероціни, які синтезують штами ентерококів [4]. Ентероцини представляють великий інтерес через їх антимікробну активність щодо таких патогенних бактерій як Listeria monocytogenes, Staphylococcus aureus, Clostridium spp [4]. Штам E. italicus ONU547 був ізольований співробітником кафедри мікробіології, вірусології та біотехнології ОНУ імені І.І. Мечникова Мерлічем А. Г. [14]. Бактеріоцин, вироблений цим штамом, виявляв антимікробну активність щодо L. sakei subsp. sakei JCM 1157, Brochothrix thermosphacta DSMZ 20171 та Listeria ivanovii subsp. ivanovii DSMZ 20750. Молекулярна маса бактеріоцинів або компонентів одного бактеріоцину, виробленого E. italicus ONU547, становила приблизно 2 та 3 кДа [14].

Крім того, в останні роки збільшилася кількість досліджень щодо вивчення антимікробної активності ефірних олій, які, завдяки своїм потенційним антимікробним властивостям, отримали назву «фітобіотики» $[3,18]$. Рядом дослідників визначено позитивний вплив ефірних олій на організм людини і тварин, зокрема на процеси травлення (стимуляція утворення ферментів), причому ефірні олії не пригнічують ріст представників кишкової нормобіоти $[7,11,17]$. Тому нові біотехнологічні препарати на основі комбінацій ефірних олій 3 пробіотичними штамами бактерій або з бактеріоцинами можуть бути гідним доповненням до антибіотиків $[1,2,6,9,16]$.

Ефективність використання ефірних олій у комбінації з бактеріоцинами залежить від їх оптимального дозування: невеликі концентрації ефірних олій ефективно знищують хвороботворні мікроорганізми, не завдаючи шкоди корисним бактеріям, які мешкають у кишківнику людини. Цей феномен уможливлює одночасне введення бактеріоцинів або бактеріоциногенних штамів і ефірних олій для лікування кишкових розладів людини, викликаних патогенними мікроорганізмами; можливо також сукупне додавання бактеріоцинів і ефірних олій у кисломолочні продукти (ароматизовані напої або йогурти) [13, 20].

Однак, протимікробна активність природних ефірних олій різного походження істотно відрізняється, а також суттєво залежить від бактерії-мішені. Тому створення комбінації ефірних олій та бактеріоцинів є важливим для розробки препаратів з метою використання у харчових та фармацевтичних біотехнологіях, а також для контролю збудників псування харчових продуктів та харчових отруєнь.

Метою роботи була оцінка впливу бактеріоцину штаму Enterococcus italicus ONU 547 та ефірних олій окремо та в комбінації проти тест-штамів умовно-патогенних мікроорганізмів.

\section{Матеріали та методи}

В роботі були використані тест-штами: Salmonella enterica NCTC 6017, Escherichia coli ATCC 25922, Pseudomonas aeruginosa ATCC 27853, Pseudomonas putida KT 2440, Enterococcus faecalis ATCC 29212, Klebsiella pneumoniae ATCC 10031, Staphylococcus aureus ATCC 25923, отримані 3 колекції культур кафедри мікробіології, вірусології та біотехнології ОНУ імені I.I. Мечникова. Штами культивували на МПА (м'ясо пептонний агар) при 
$37{ }^{\circ} \mathrm{C}$ та зберігали при $4{ }^{\circ} \mathrm{C}$. Усі експерименти із тест-штамами проводили на середовищі LB (Луріа-Бертані) такого складу (г/л): пептон - 15,0, дріжджовий екстракт - 10,0, хлорид натрію - 5,0, агар -11,0 г/л.

Для отримання безклітинного супернатанту що містить бактеріоцин, штам Enterococcus italicus ONU 547 культивували в рідкому середовищі MRS при $30{ }^{\circ} \mathrm{C}$ протягом 17 год. Отриману нічну культуру центрифугували при 10000 g протягом 15 хвилин, з подальшою нейтралізацією $1 \mathrm{M} \mathrm{NaOH}$ та стерилізацією при $100{ }^{\circ} \mathrm{C}$ протягом 10 хвилин на водяній бані $[4,9,14]$.

Для експерименту були обрані ефірні олії (ЕО) фірми «Лія» шести рослин (Полин солянковидний, Чебрець садовий, Аніс лікарський, Чайне дерево, Ялиця сибірська, Меліса лікарська), вибір яких був зумовлений їх антимікробним потенціалом до патогенних мікроорганізмів [10]. Основні активні речовини дослідних ефірних олій наведено у таблиці 1.

Таблиця 1

Активні речовини ефірних олій, що використовували при дослідженні (основні складові) [10]

Table1

Active substances of essential oils used in the study (main components) [10]

\begin{tabular}{|c|c|}
\hline Джерело ефірної олії (ЕО) & Основні активні речовини \\
\hline $\begin{array}{l}\text { Полин солянковидний } \\
\text { (Artemisia salsoloides) }\end{array}$ & $\begin{array}{l}\text { Лімонен, транс- } \beta \text {-оцімен, цис- } \beta \text {-оцімен, } \alpha \text {-пінен, } \beta \text {-мірцен, } \\
\beta \text {-пінен. }\end{array}$ \\
\hline $\begin{array}{l}\text { Чебрець садовий } \\
\text { (Thymus vulgaris) }\end{array}$ & Ліналоол, ліналілацетат \\
\hline $\begin{array}{l}\text { Аніс лікарський } \\
\text { (Anisum officinalisa) }\end{array}$ & $\begin{array}{l}\text { Анетол, метилхавікол, } \alpha \text {-фелландрен, лімонен, дипентен, } \\
\alpha \text {-пінен, камфен, } \gamma \text {-бісаболен, } \beta \text {-фарнезен, } \gamma \text {-гімахален, } \\
\text { куркума, анісовий альдегід, аніскетон, гідрохінон, } \\
\text { n-креозол, пропіонова, масляна, міристинова і анісова } \\
\text { кислоти }\end{array}$ \\
\hline $\begin{array}{l}\text { Чайне дерево (Melaleuca } \\
\text { alternifolia) }\end{array}$ & $\begin{array}{l}\text { Терпінен-4-оl, } \gamma \text {-терпінен, } \alpha \text {-терпінен, } 1,8 \text {-цинеол, } \\
\alpha \text {-терпінолен, } \alpha \text {-терпінеол, } \alpha \text {-пінен та р-цімол }\end{array}$ \\
\hline $\begin{array}{l}\text { Ялиця сибірська } \\
\text { (Abies sibirica) }\end{array}$ & $\begin{array}{l}\text { Мірцен, цис- і транс- } \beta \text {-оцімен, лімонен, дипентен, терпени, } \\
\text { терпінолен, } \alpha \text { - і } \beta \text {-пінени, камфен, } \alpha \text {-туйен, } \alpha \text {-фенхен, } \\
3 \text {-карен, } \gamma \text {-бісаболен n-цимол, борнеол, цинеол, деканаль, } \\
\text { додекан }\end{array}$ \\
\hline $\begin{array}{l}\text { Меліса лікарська } \\
\text { (Melissa officinalis) }\end{array}$ & $\begin{array}{l}\text { Мірцен, ліналоол, камфора, цитронелаль, } \beta \text { - каріофілен, } \\
\text { оксид каріофілен, цитраль }\end{array}$ \\
\hline
\end{tabular}

Для приготування суміші ефірних олій використовували 0,4\% (вага/ об'єм) ефірної олії, 0,5\% (вага/об'єм) Твін 20 і 6,0\% (вага/об'єм) диметилсульфоксиду (ДМСО) і доводили на шейкері-інкубаторі при 200 об/хв протягом 30 хв до стану емульсії. Твін 20 і ДМСО використовували для стабілізації емульсії. Всі ці речовини змішували у стерильних умовах у рідкому середовищі LB (кінцевий об'єм 10 мл) [19].

Для визначення антагоністичної активності ефірних олій і бактеріоцину, при їх окремому використанні, в кожну лунку 96-лункового мікропланшету додавали 100 мкл середовища LB, 50 мкл нічної культури тест-штамів 
бактерій та 100 мкл речовини, яку тестували. Як контроль використовували середовище LB (200 мкл) з додаванням нічної культури тест-штаму (50 мкл) [19].

Для визначення антагоністичної активності ефірних олій і бактеріоцину, при їх сумісному використанні, в кожну лунку 96-лункового мікропланшету додавали 100 мкл середовища LB, 50 мкл нічної культури тест-штамів бактерій та 100 мкл сполуки, що містить стабілізовану емульсію ефірної олії та бактеріоцин. Як контроль використовували середовище LB (200 мкл) з додаванням нічної культури тест-штаму (50 мкл) [19].

Планшети інкубували при $37^{\circ} \mathrm{C}$ протягом 24 год, після чого вимірювали оптичну щільність суспензії (за довжиною хвилі 600 нм). Усі досліди були виконані в трьох повторах на мікропланшетному спектрофотометрі $\mu$ Quant.

Для визначення синергічних ефектів ефірних олій і бактеріоцину розраховували індекс фракційної пригнічувальної концентрації (FIC) шляхом складання значень FIC бактеріоцину штаму E. italicus ONU 547 (a) і ефірних олій (b) таким чином [19]:

$$
\begin{aligned}
& \mathrm{FIC}=(\mathrm{FICa}+\mathrm{FICb}), \text { якщо } \\
& \mathrm{FICa}=\frac{\text { сукупний антимікробний ефект ефірної олії та бактеріоцину }}{\text { антимікробна активність бактеріоцину }} \\
& \mathrm{FICb}=\frac{\text { сукупний антимікробний ефект ефірної олії та бактеріоцину }}{\text { антимікробний ефект ефірної олії }}
\end{aligned}
$$

Для інтерпретації результатів використовували шкалу, де $\mathrm{FIC} \leq 0,5$ приймали як синергічний ефект (S), $0,5 \leq$ FIC $\leq 2$ - інтерактивний ефект (I) - відсутність ефекту взаємодії, $2<$ FIC $\leq 3$ - адитивний ефект (AD), FIC $>3$ - антагоністичний ефект двох сполук, що тестували (А) [19].

\section{Результати досліджень та їх обговорення}

За результатами дослідження окремого впливу бактеріоцину та ефірних олій показано, що на тест-штам S. enterica NCTC 6017 максимальний вплив показала ЕО Меліси лікарської та бактеріоцин, який продукує штам E. italicus ONU 547. Зниження життєздатності тест-штаму склало 77,7\% та 21,9\%, відповідно (рис. 1). Незначне пригнічення росту (до 10,0\%) індикаторного штамy S. enterica NCTC 6017 спостерігали при додаванні ЕО Анісу лікарського та ЕО Чебрецю садового.

Вплив дослідних ефірних олій на індикаторний штам $P$. aeruginosa ATCC 27853 був майже однаковим - зниження життєздатності клітин спостерігали в межах 23,1-32,8\%. Бактеріоцин, що використовували у роботі, майже не впливав на життєздатність $P$. aeruginosa ATCC 27853 (рис. 2).

Зниження життєздатності тест-штаму P. putida КТ 2440 до 41,0\% реєстрували при використанні ЕО Меліси лікарської та до 52,1\% при використанні ЕО Чайного дерева (рис. 3). Антимікробна дія бактеріоцину та ЕО Полину солянковидного викликала пригнічення росту штаму P. putida KT 2440 на $18,8 \%$. 
ЕО Чайного дерева пригнічувала ріст індикаторного штаму K. pneumoniae АТCC 10031 на 72,3\% у порівнянні $з$ контролем, а ЕО Меліси лікарської - на 57,9\% (рис. 4). ЕО Анісу лікарського та Ялиці сибірської, навпаки, стимулювали ріст індикаторного штаму на 46,5\% та 58,4\%, відповідно (рис. 4). Бактеріоцин, якій продукує штам Enterococcus italicus ONU 547, пригнічував ріст індикаторного штаму на 29,8\% (рис. 4).

Було виявлено, що дослідні бактеріоцин та ефірні олії діяли майже однаково на життєздатність тест-штаму E. coli ATCC 25922 (рис. 5). Максимально впливали на даний тест-штам ЕО Полину солянковидного та Анісу лікарського: життєздатність кишкової палички була знижена на 43,9\% та 47,7\%, відповідно (рис. 5).

Досить цікаві результати були отримані за впливом ефірних олій на індикаторний штам E. faecalis ATCC 29212. В цьому досліді не спостерігали пригнічення росту даного штаму, навпаки - реєстрували стимуляцію його росту на $31-91,0 \% \%$ (рис. 6 ).

При дослідженні зміни ростових показників тест-штаму $S$. aureus ATCC 25923 за впливом ефірних олій реєстрували антимікробну дію ЕО Анісу лікарського та ЕО Полину солянковидного - кількість життєздатних клітин тест-штаму знижувалась на 22,9 та 34,1\%, відповідно, у порівнянні 3 контролем (рис. 7).

EO Полину (Artemisia) містить монотерпени, які руйнують мембрани стафілококу золотистого та деяких видів стрептококів [12]. Бактеріоцин Enterococcus italicus ONU 547, навпаки, стимулював ріст тест-штаму S. aureus АTCC 25923 на 27,1\%. Інші ефірні олії також спричиняли стимулювальну дію.

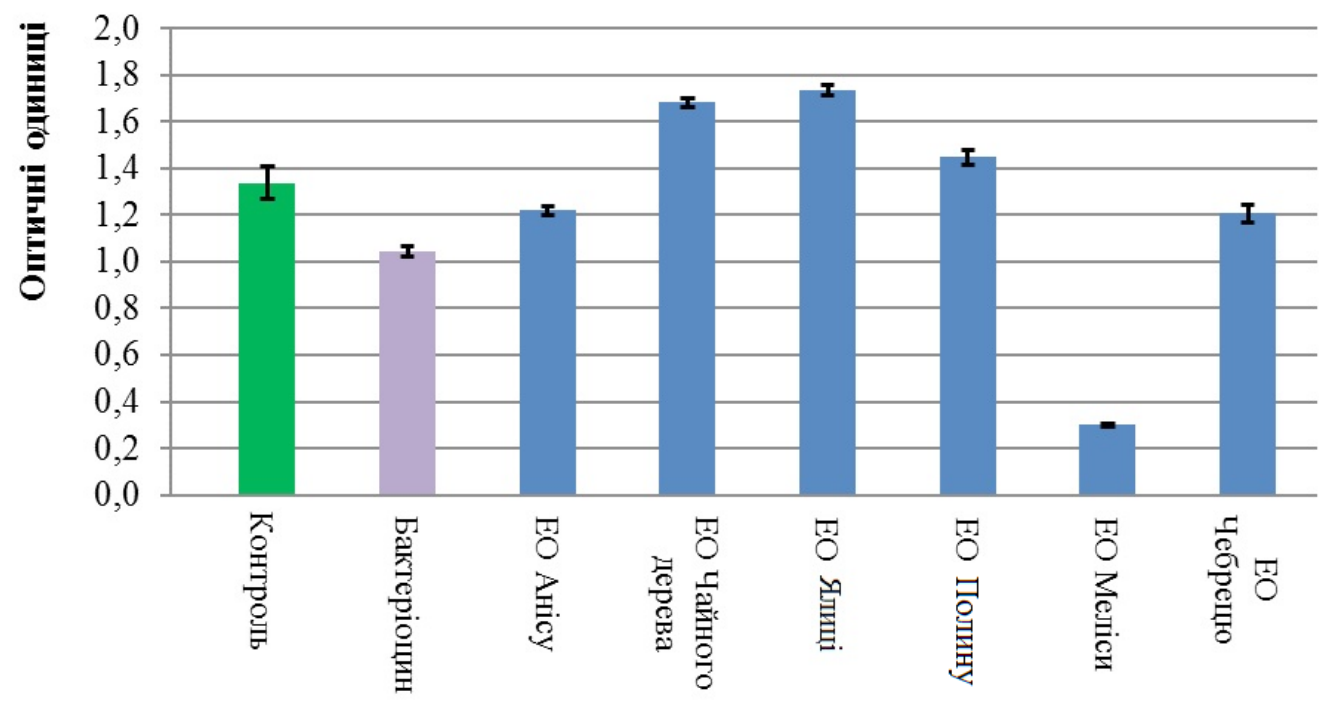

Рис. 1. Вплив ефірних олій та бактеріоцину на показники оптичної густини Salmonella enterica NCTC 6017

Fig. 1. The effect of essential oils and bacteriocin on the optical density of Salmonella enterica NCTC 6017 


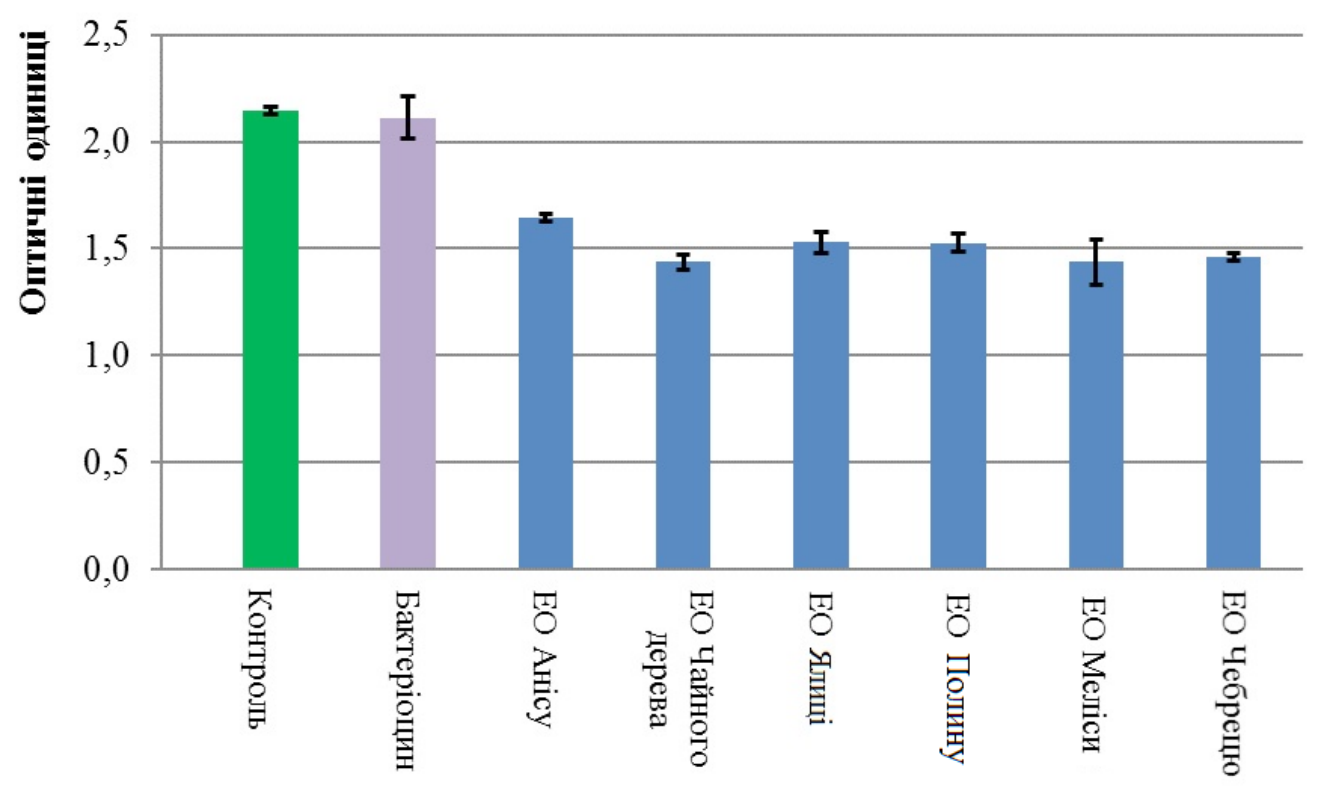

Рис. 2. Вплив ефірних олій та бактеріоцину на показники оптичної густини Pseudomonas aeruginosa ATCC 27853

Fig. 2. The effect of essential oils and bacteriocin on the optical density of Pseudomonas aeruginosa ATCC 27853

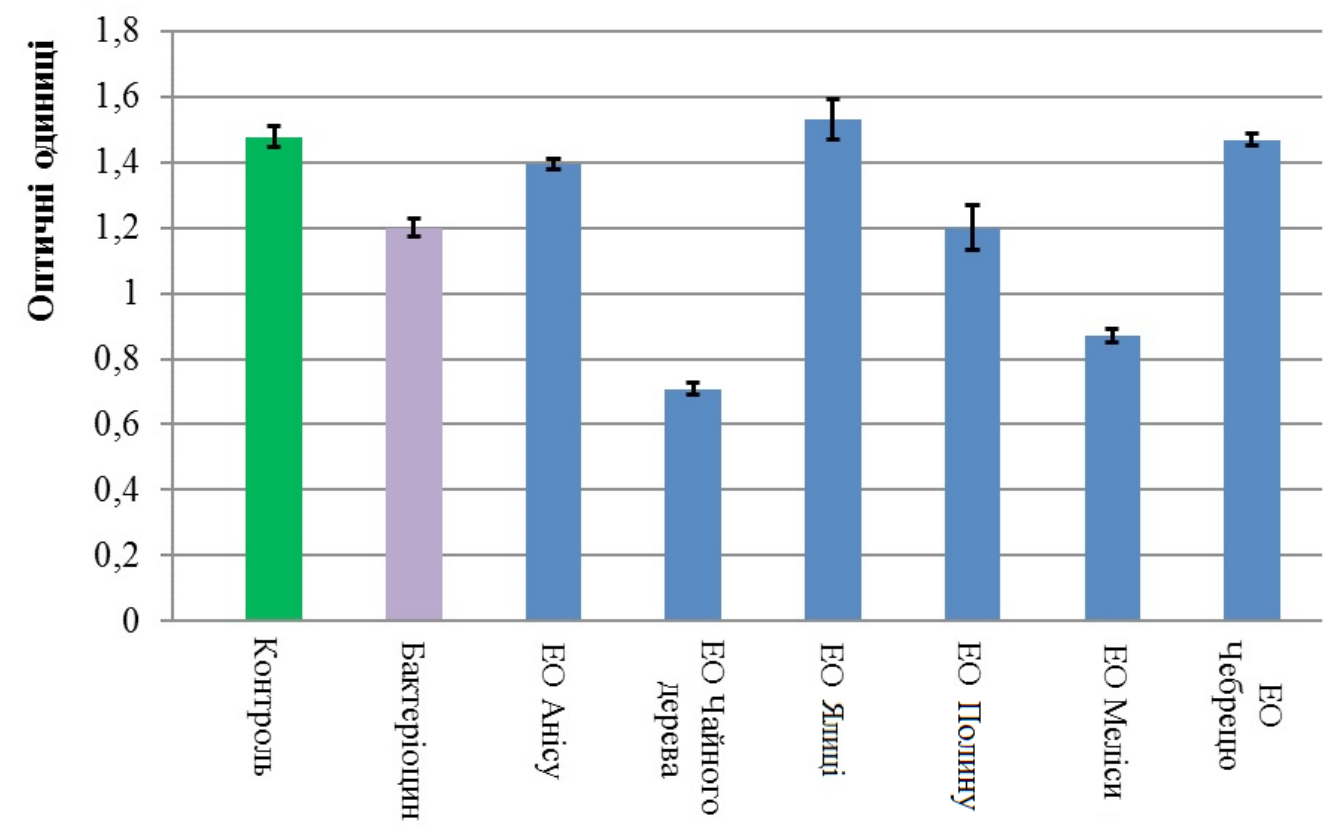

Рис. 3. Вплив ефірних олій та бактеріоцину на показники оптичної густини Pseudomonas putida KT 2440

Fig. 3. The effect of essential oils and bacteriocin on the optical density of Pseudomonas putida KT 2440 


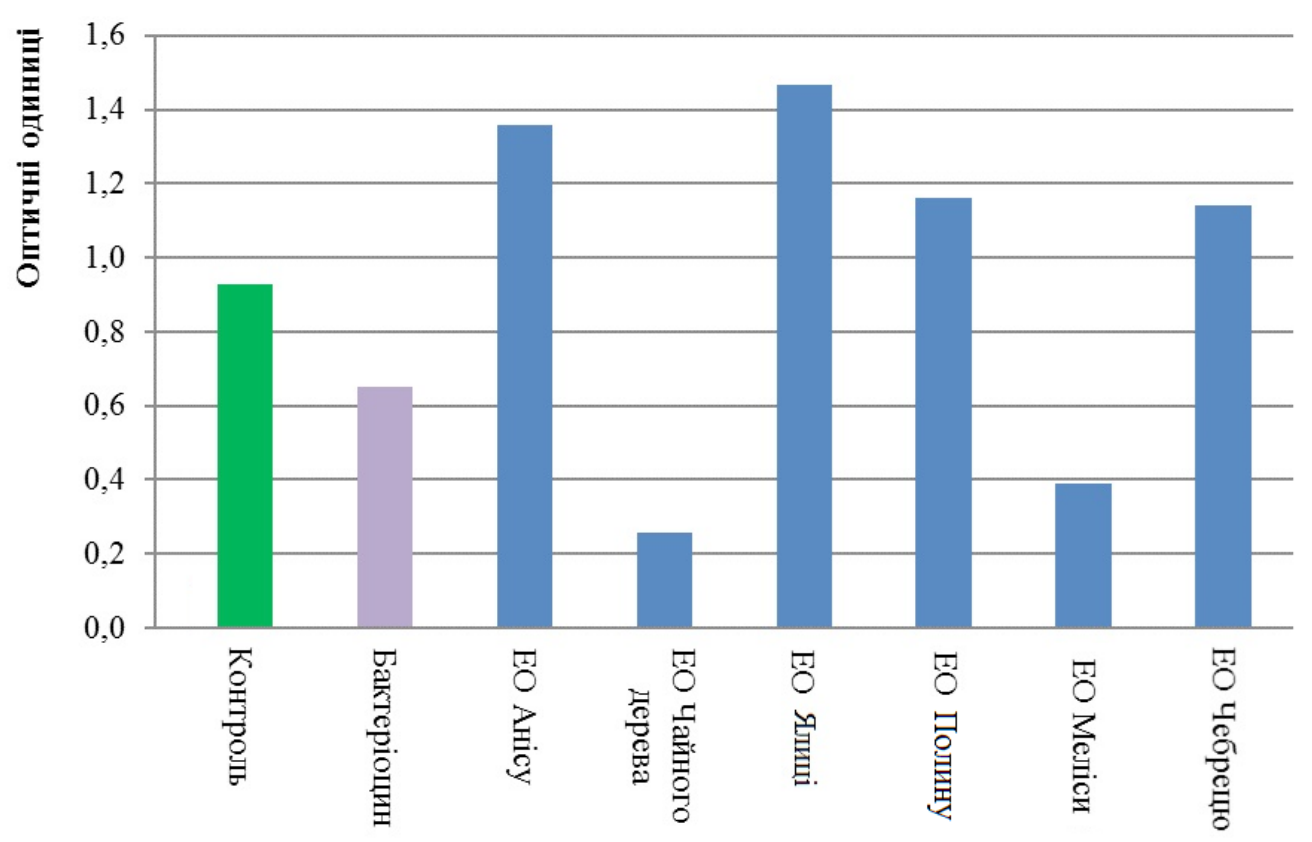

Рис. 4. Вплив ефірних олій та бактеріоцину на показники оптичної густини Klebsiella pneumoniae ATCC 10031

Fig. 4. The effect of essential oils and bacteriocin on the optical density of Klebsiella pneumoniae ATCC 10031

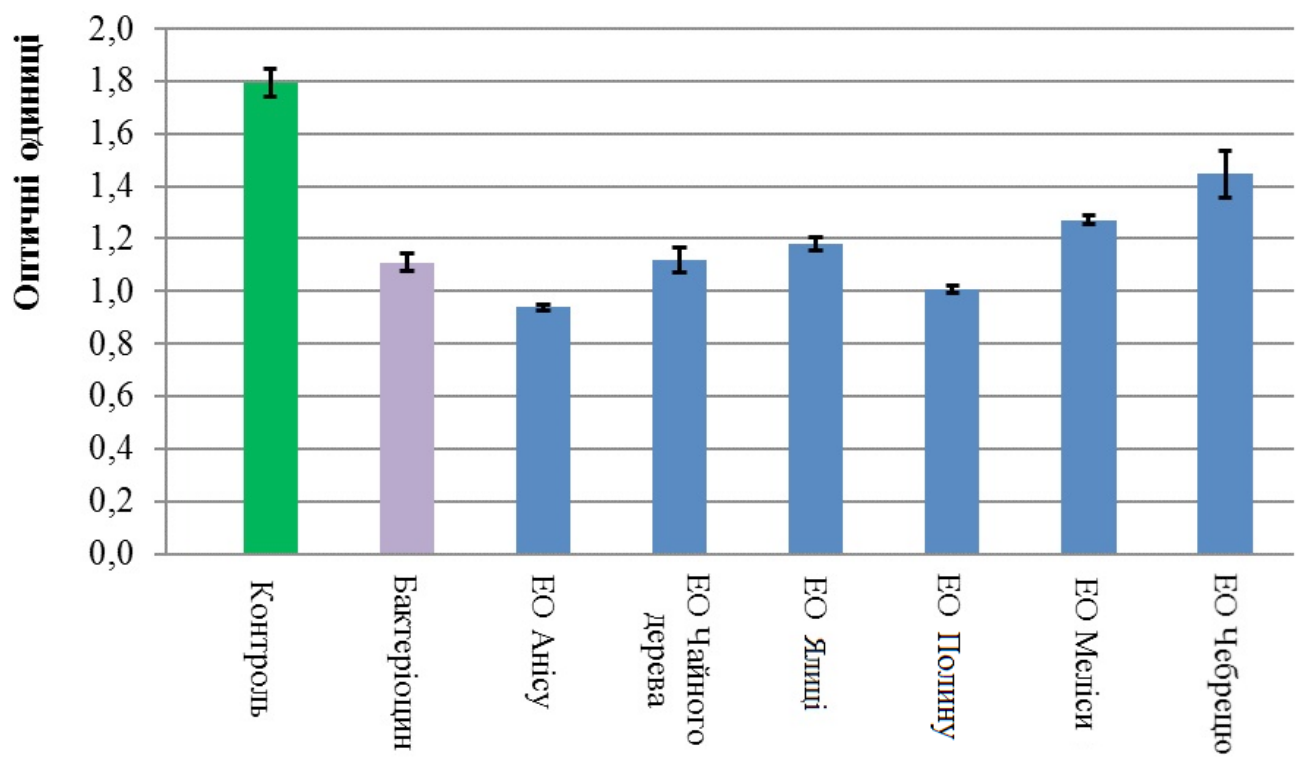

Рис. 5. Вплив ефірних олій та бактеріоцину на показники оптичної густини Escherichia coli ATCC 25922

Fig. 5. The effect of essential oils and bacteriocin on the optical density of Escherichia coli ATCC 25922 


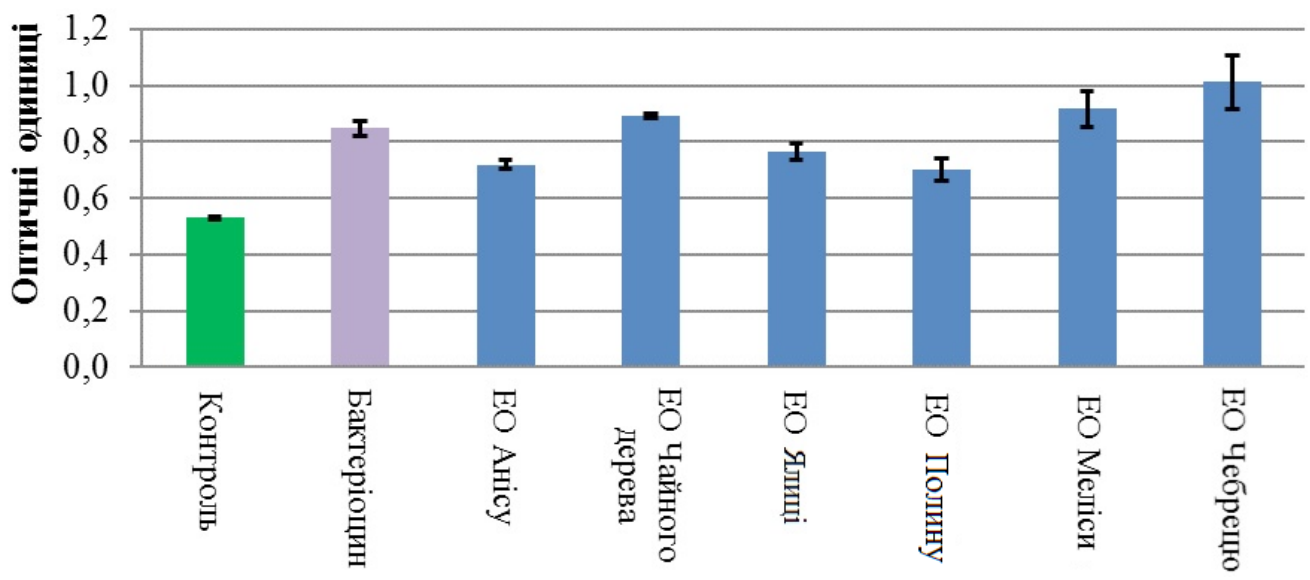

Рис. 6. Вплив ефірних олій та бактеріоцину на показники оптичної густини Enterococcus faecalis ATCC 29212

Fig. 6. The effect of essential oils and bacteriocin on the optical density of Enterococcus faecalis ATCC 29212

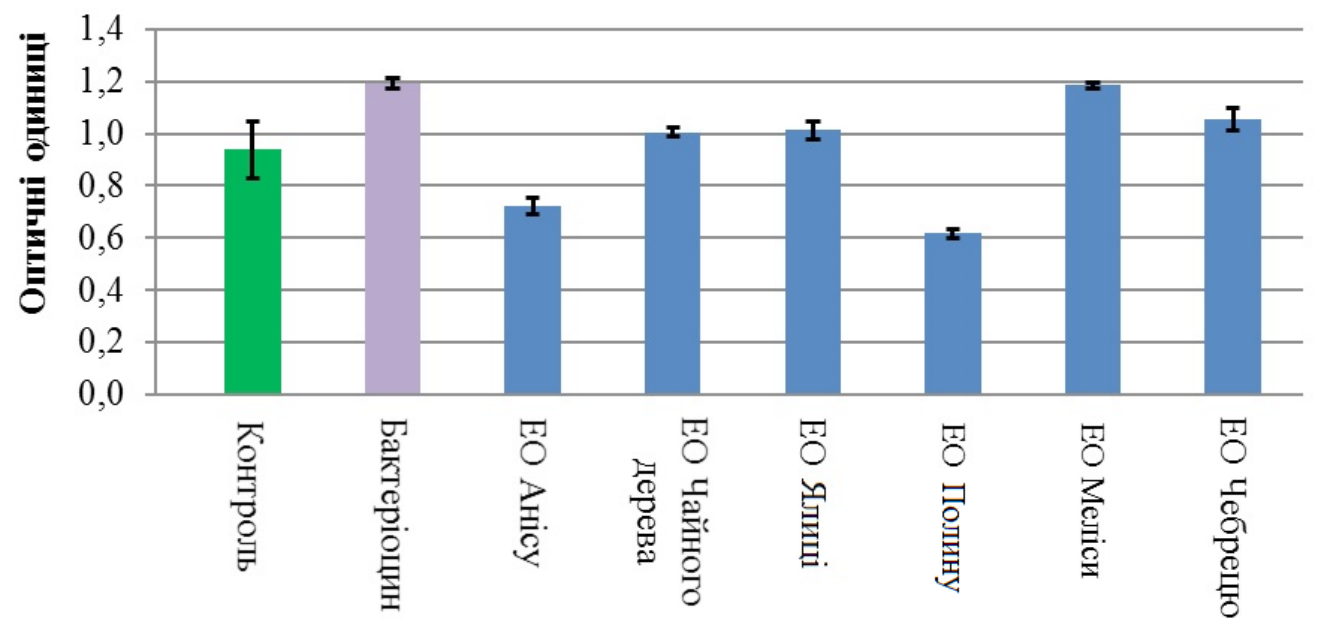

Рис. 7. Вплив ефірних олій та бактеріоцину на показники оптичної густини Staphylococcus aureus ATCC 25923

Fig. 7. The effect of essential oils and bacteriocin on the optical density of Staphylococcus aureus ATCC 25923

Результати визначення індексу фракційної пригнічувальної концентрації за сумісної дії речовин, що тестували, наведені у таблиці 2. Було визначено, що дослідні комбінації ефірних олій та бактеріоцину викликали 4 типи наслідків: 1) ефект синергії - ефект від спільної дії всіх елементів системи, що призводить до збільшення якісних показників функціонування без збільшення кількісних; 2) адитивний ефект - один із видів взаємодії лікарських субстанцій, коли фармакологічний ефект їх комбінації більш виражений, ніж одного з компонентів, але менший за передбачуваний ефект їх суми; 3) ан- 


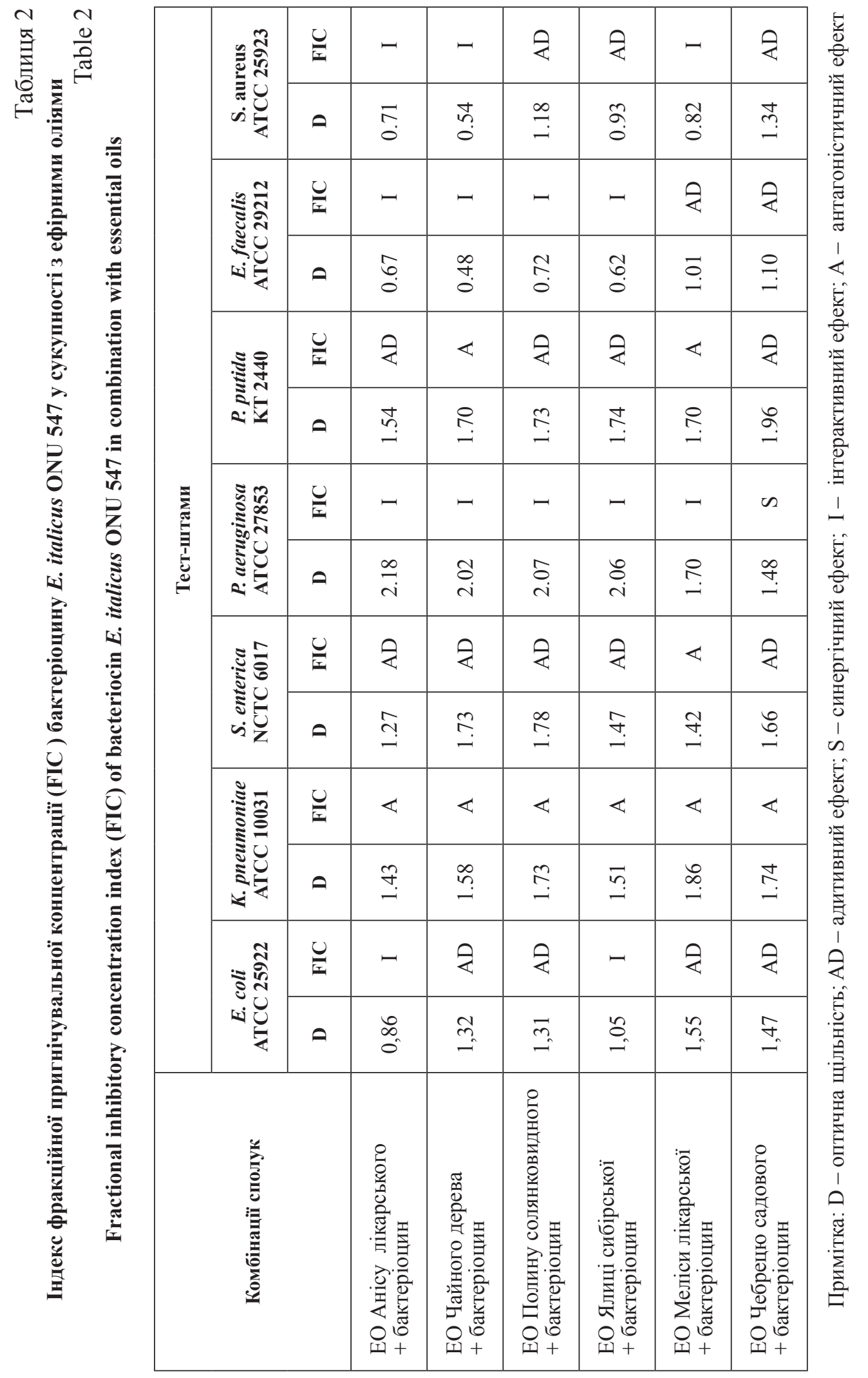


тагоністичний ефект - вид взаємодії речовин, внаслідок якої ефекти однієї 3 них (чи обох) зменшуються або втрачаються; 4) відсутність ефекту взаємодії (інтерактивний ефект).

Як видно з наведених даних, сукупна дія бактеріоцину та ЕО Анісу лікарського (Anisum officinalisa) спричиняла адитивний ефект до індикаторних штамів S. enterica NCTC 6017 та P. putida KT 2440) та антагоністичний ефект до K. pneumoniae ATCC 10031. Не спостерігали інтерактивного ефекту до E. coli ATCC 25922, P. aeruginosa ATCC 27853, E. faecalis ATCC 29212 i S. aureus ATCC 25923

Сукупна дія дослідного бактеріоцину та ЕО Чайного дерева (Anisum officinalisa) викликала адитивний ефект по відношенню до E. coli ATCC 25922 та S. enterica NCTC 6017; антагоністичний ефект до $K$. pneumoniae ATCC 10031 та P. putida KT 2440, та не викликала інтерактивного ефекту до P. aeruginosa ATCC 27853, E. faecalis ATCC 29212 i S. aureus ATCC 25923.

Спільний вплив бактеріоцину та ЕО Полину солянковидного (Artemisia salsoloides) викликав адитивний ефект до E. coli ATCC 25922, S. enterica NCTC 6017, S. aureus ATCC 25923 та P. putida KT 2440; антагоністичний ефект до K. pneumoniae ATCC 10031, та не викликала інтерактивного ефекту до P. aeruginosa ATCC 27853 та E. faecalis ATCC 29212.

Сумісна дія бактеріоцину та ЕО Ялиці сибірської (Abies sibirica) спричиняла адитивний ефект до $S$. enterica NCTC 6017, P. putida KT 2440 та S. aureus ATCC 25923; антагоністичний ефект до K. pneumoniae ATCC 10031, та не спричиняла інтерактивного ефекту до P. aeruginosa ATCC 27853, E. faecalis ATCC 29212 i E. coli ATCC 25922.

Спільний вплив бактеріоцину та ЕО Меліси лікарської(Melissa officinalis) спричиняв адитивний ефект до E. coli ATCC 25922 та E. faecalis ATCC 29212; антагоністичний ефект до K. pneumoniae ATCC 10031, S. enterica NCTC 6017 та $P$. putida КТ 2440 та не спричиняв інтерактивного ефекту до $P$. aeruginosa ATCC 27853 i $S$. aureus ATCC 25923.

Сукупна дія дослідного бактеріоцину та ЕО Чебрецю садового (Thymus vulgaris) спричиняла адитивний ефект до E. coli ATCC 25922, S. enterica NCTC 6017, E. faecalis ATCC 29212, S. aureus ATCC 25923 та P. putida KT 2440; антагоністичний ефект до $K$. pneumoniae ATCC 10031 та синергічний ефект до P. aeruginosa ATCC 27853.

Таким чином було показано, що більшість дослідних природних ефірних олій викликає пригнічення росту індикаторних штамів умовно-патогенних мікроорганізмів. Максимальний антимікробний ефект до індикаторних штамів продемонстрували ефірні олії Анісу лікарського та Меліси лікарської, які пригнічували ріст E. coli ATCC 25922, S. enterica NCTC 6017, P. putida KT 2440, P. aeruginosa ATCC 27853 та K. pneumoniae АTCC 10031 більше ніж на $50,0 \%$.

Ефірні олії мають величезний комерційний потенціал на світовому ринку завдяки своїм унікальним смаковим і ароматичним властивостям, а також біологічній активності [8]. Нашими дослідженнями підтверджено протимікробну дію хімічних компонентів природних ефірних олій, що висвітлено в літературних джерелах [10]. Крім того, отримані результати продемонструва- 
ли синергічний ефект будь-яких двох або більше інгредієнтів ефірних олій проти різних патогенів людини, що підтверджують публікації низки авторів $[11,13,14,16]$.

При дослідженні сукупної антимікробної дії бактеріоцину Enterococcus italicus ONU 547 та ефірних олій було показано, що такий спільний вплив спричиняє здебільшого синергічний або адитивний ефекти. Ці результати надають підставу для подальшої розробки комбінацій ефірних олій та бактеріоцинів або бактеріоціногенних штамів 3 метою використання у харчових та фармацевтичних біотехнологіях.

\author{
N. Yu. Vasylieva, G.V. Yamborko, A.G. Merlich, \\ I. V. Strashnova, I.P. Metelitsina \\ Odesa National I. I. Mechnykov University, \\ 2, Dvorianska str., Odesa, 65082, Ukraine, \\ e-mail: tatkamic@onu.edu.ua
}

\title{
THE EFFECT OF BACTERIOCIN \\ ENTEROCOCCUS ITALICUS ONU 547 AND ESSENTIAL OILS ON THE GROWTH OF OPPORTUNISTIC MICROORGANISMS
}

\begin{abstract}
Summary
Purpose. To evaluate the effectiveness of bacteriocin of Enterococcus italicus ONU 547 and essential oils individually and in combination against indicator strains of opportunistic pathogens. Methods. The antagonistic activity of essential oils and bacteriocin was determined by the optical density of the bacterial suspension of test strains (Salmonella enterica NCTC 6017, Escherichia coli ATCC 25922, Pseudomonas aeruginosa ATCC 27853, Pseudomonas putida KT 2440, Enterococcus faecalis ATCC 29212, Klebsiella pneumoniae ATCC 10031, Staphylococcus aureus ATCC 25923). The index of fractional inhibitory activity (FIC) was calculated by adding the FIC values of bacteriocin E. italicus ONU 547 and the studied essential oils. The results. The maximum antimicrobial effect was caused by the essential oils of Anisum officinalis and Melissa officinalis, which suppressed the growth of test strains more than $50.0 \%$. When using bacteriocin of E. italicus ONU 547 suppression of viability of indicator strains did not exceed 30.0\%. Experimental combinations of essential oils and bacteriocin caused 4 types of consequences: synergy effect; additive effect; antagonistic effect; interactive effect (no interaction effect). In most cases, the combined action of bacteriocin and essential oils caused an additive effect. Conclusions. This study demonstrated the potential of using different combinations of natural antimicrobial compounds. The obtained results provide grounds for further development and optimization of combinations of essential oils and probiotic strains of microorganisms for use in food and pharmaceutical biotechnology.
\end{abstract}

Key words : antimicrobial activity, essential oils, bacteriocin 
Н.Ю. Васильева, А.В. Ямборко, А.Г. Мерлич,

И.В. Страшнова, И.П. Метелицина

Одесский национальный университет имени И.И. Мечникова, ул. Дворянская, 2, Одесса, 65082, Украина, e-mail: tatkamic@onu.edu.ua

\title{
ВЛИЯНИЕ БАКТЕРИОЦИНА \\ ENTEROCOCCUS ITALICUS ONU 547 И ЭФИРНЫХ МАСЕЛ НА РОСТ УСЛОВНО-ПАТОГЕННЫХ МИКРООРГАНИЗМОВ
}

\begin{abstract}
Реферат
Цель. Оиенить влияние бактериоцина Enterococcus italicus ONU 547 и эфирных масел по отдельности и в комбинации к тест-итаммам условно-патогенных микроорганизмов. Методы. Антагонистической активностью бактериочинов и эфирных масел определяли по показателю оптической плотности суспензии бактерий тест-итаммов (Salmonella enterica NCTC 6017, Escherichia coli ATCC 25922, Pseudomonas aeruginosa ATCC 27853, Pseudomonas putida KT 2440, Enterococcus faecalis ATCC 29212, Klebsiella pneumoniae ATCC 10031, Staphylococcus aureus ATCC 25923). Индекс фракичионой ингибирующей активности (FIC) рассчитывали путем сложения значений FIC бактериоцина E. italicus ONU 547 и исследованных эфирных масел. Результаты. Максимальный антимикробный эффект вызыьвали эфирные масла Аниса лекарственного (Anisum officinalis) и Мелиссы лекарственной (Melissa officinalis), которые подавляли рост тест-итаммов более чем на 50,0\%. При использовании бактериоччина E. italicus ONU 547 yzнетение жизнеспособности индикаторных штаммов не превышало 30,0\%. Oпьтнные комбинации эфирных масел и бактериоцина вызывали 4 типа последствий: эффект синергии; аддитивный эффект; антагонистический эффект; интерактивный эффект (отсутствие эффекта взаимодействия). В большинстве случаев совокупное действие бактериоцина и эфирных масел вызвало аддитивный эффект. Выводы. Это исследование продемонстрировало потенциал использования различных комбинаций природных противомикробных соединений. Полученнье результаты дают основания для дальнейшей разработки и оптимизации комбинаций эфирных масел и пробиотических штаммов микроорганизмов с иелью использования в пищевых и фармачевтических биотехнологиях.
\end{abstract}

Ключевые слова: антимикробная активность, эфирные масла, бактериоичин

\section{СПИСОК ВИКОРИСТАНОЇ ЛІТЕРАТУРИ}

1. Крюков В.С., Глебова И.В. Антибактериальное действие эфирных масел лекарственных растений (обзор) // Проблемы биологии продуктивных животных - 2017. - Т. 3.- C. 5-25.

2. Acamovic T., Brooker J.D. Biochemistry of plant secondary metabolites and their effect in animal // Proc. Nutr. Soc. - 2005. - V. 64. - P. 403-412.

3. Akhtar M.S., Degaga B., Azam T. Antimicrobial activity of essential oils extracted from medicinal plants against the pathogenic microorganisms: a re- 
view // Biological Sciences and Pharmaceutical Research. - 2014. - V. 2, № 1. P. 1-7.

4. Gaaloul N., Braiek O.B., Berjeaud J.M., Arthur T. Evaluation of antimicrobial activity and safety aspect of Enterococcus Italicus GGN10 strain isolated from tunisian bovine raw milk // Journal of Food Safety. - 2014.- V. 34, № 4. - P. 300-311.

5. Gillor O., Etzion A., Riley M. A. The dual role of bacteriocins as anti- and probiotics // Appl. Microbiol. Biotechnol. - 2008. - V.81, № 4. - P. 591-606.

6. Hammer K. A., Carson C.F., Thormar H. Antibacterial and antifungal activities of essential oils. - London, UK: John Wiley \& Sons, 2011. - P. 255-306.

7. Hawrelak J.A., Cattley T., Myers S.P. Essential oils in the treatment of intestinal dysbiosis: a preliminary in vitro study // Alternative Medicine Review. - 2009. - V. 14, № 4. - P. 380-384.

8. Hwanhlem N., Biscola V., El-Ghaish Sh. Bacteriocin-producing lactic acid bacteria isolated from mangrove forests in southern Thailand as potential bio-control agents: purification and characterization of bacteriocin produced by Lactococcus lactis subsp. lactis KT2W2L // Probiotics Antimicrob. Proteins. - 2013. - V. 5. - P. 264-278.

9. Iseppi R., Camellini S., Sabia C., Messi P. Combined antimicrobial use of essential oils and bacteriocin bacLP17 as seafood biopreservative to control Listeria monocytogenes both in planktonic and in sessile forms // Res Microbiol. - 2020. - V.171, № 8. - P. 351-356.

10. Joy B., Raja A., Abraham E. Antimicrobial activity and chemical composition of essential oil from Hedychium coronarium // Phytotherapy Research. - 2007. - V. 21, № 5. - P. 439-443.

11. Koch C., Reichling J., Schnitzler P. Essential oils inhibit the replication of herpes simplex virus type 1 (HSV-1) and type 2 (HSV-2) // Botanical Medicine in Clinical Practices. -Wallingsford, Calif, USA: CABI, 2008. - C. 192-197.

12. Koroch A., Juliani H.R., Zygadlo J.A. Bioactivity of essential oils and their components. In: Berger R. G., editor // Flavours and Fragrances Chemistry, Bioprocessing and Sustainability. - Berlin, Germany: Springer, 2007. P. $87-115$.

13. LeBel G., Vaillancourt K., Bercier P., Grenier D. Antibacterial activity against porcine respiratory bacterial pathogens and in vitro biocompatibility of essential oil // Arch. Microbiol. - 2019. - V. 201, № 6. - P. 833-840.

14. Merlich A., Galkin M., Choiset Y., Limanska N., Vasylieva N., Ivanytsia V., Haertle $T$. Characterization of the bacteriocin produced by Enterococcus italicus ONU547 isolated from Thai fermented cabbage // Folia Microbiologica. - 2019. - V. 64, № 4. - P. 535-545

15. Nazzaro F., Fratianni F., De Martino L., Coppola R., De Feo V. Effect of essential oils on pathogenic bacteria // Pharmaceuticals. - 2013. - V.6, № 12. - P. 1451-1474.

16. Pasqua R. Di., De Feo V., Villani F., Mauriello G. In vitro antimicrobial activity of essential oils from Mediterranean Apiaceae, Verbenaceae and Lamiaceae against foodborne pathogens and spoilage bacteria // Annals of Microbiology. - 2005. - V. 55, № 2. - P. 139-143. 
17. Pourghanbari G., Nili H., Moattari A., Mohammadi A., Iraji A. Antiviral activity of the oseltamivir and Melissa officinalis L. essential oil against avian influenza A virus (H9N2) // Virus Disease. - 2016. - V. 27, № 2. - P. 170-178.

18. Karmakar S., Khare R. S., Ojha S., Kundu K., Kundu S. Development of Probiotic Candidate in Combination with Essential Oils from Medicinal Plant and Their Effect on Enteric Pathogens: A Review // Gastroenterol Res Pract. - 2012. - V. 2012. - Article ID 457150.

19. Turgis M., Dang V. K., Dupont C., Lacroix M. Combined antimicrobial effect of essential oils and bacteriocins against foodborne pathogens and food spoilage bacteria // Food Research International. - 2012. -V. 48, № 2. P. 696-702

20. Yang C., Chowdhury M., Huo Y., Gong J. Phytogenic compounds as alternatives to in-feed antibiotics: potentials and challenges in application // Pathogens. - 2015. - V. 4, № 1. - P. 137-156.

\section{REFERENCES}

1. Kryukov VS. Glebova IV. Antibacterial action of essential oils of medicinal plants (review). Problemy biologii produktivnykh zhivotnykh. 2017;3:5-25. [In Russian].

2. Acamovic T, Brooker JD. Biochemistry of plant secondary metabolites and their effect in animal. Proc. Nutr. Soc. 2005; 64:403-412.

3. Akhtar MS, Degaga B, Azam T. Antimicrobial activity of essential oils extracted from medicinal plants against the pathogenic microorganisms: a review. Biological Sciences and Pharmaceutical Research. 2014; 2(1):1-7.

4. Gaaloul N, Braiek OB, Berjeaud JM, Arthur T. Evaluation of antimicrobial activity and safety aspect of Enterococcus Italicus GGN10 strain isolated from tunisian bovine raw milk. Journal of Food Safety. 2014;34(4): 300-311.

5. Gillor O, Etzion A, Riley M.A. The dual role of bacteriocins as anti- and probiotics // Appl. Microbiol. Biotechnol. 2008;81(4): 591-606.

6. Hammer KA, Carson CF, Thormar H. Antibacterial and antifungal activities of essential oils. London, UK: John Wiley \& Sons, 2011, 255-306.

7. Hawrelak JA, Cattley T, Myers SP. Essential oils in the treatment of intestinal dysbiosis: a preliminary in vitro study. Alternative Medicine Review. 2009;14(4):380-384.

8. Hwanhlem N, Biscola V, El-Ghaish Sh. Bacteriocin-producing lactic acid bacteria isolated from mangrove forests in southern Thailand as potential bio-control agents: purification and characterization of bacteriocin produced by Lactococcus lactis subsp. lactis KT2W2L. Probiotics Antimicrob. Proteins. 2013;5:264-278.

9. Iseppi R, Camellini S, Sabia C, Messi P. Combined antimicrobial use of essential oils and bacteriocin bacLP17 as seafood biopreservative to control Listeria monocytogenes both in planktonic and in sessile forms. Res. Microbiol. 2020;171(8):351-356.

10. Joy B, Raja A, Abraham E. Antimicrobial activity and chemical composition of essential oil from Hedychium coronarium. Phytotherapy Research. 2007;21(5):439-443. 
11. Koch C, Reichling J, Schnitzler P. Essential oils inhibit the replication of herpes simplex virus type 1 (HSV-1) and type 2 (HSV-2). Botanical Medicine in Clinical Practices. Wallingsford, Calif, USA: CABI, 2008, 192-197.

12. Koroch A, Juliani HR, Zygadlo JA. Bioactivity of essential oils and their components. In: Berger R. G., editor. Flavours and Fragrances Chemistry, Bioprocessing and Sustainability. Berlin, Germany: Springer, 2007, 87-115.

13. Le Bel G, Vaillancourt K, Bercier P, Grenier D. Antibacterial activity against porcine respiratory bacterial pathogens and in vitro biocompatibility of essential oil. Arch. Microbiol. 2019;201(6): 833-840.

14. Merlich A, Galkin M, Choiset Y, Limanska N, Vasylieva N, Ivanytsia V, Haertlé T. Characterization of the bacteriocin produced by Enterococcus italicus ONU547 isolated from Thai fermented cabbage. Folia Microbiologica. 2019; 64(4):535-545

15. Nazzaro F, Fratianni F, De Martino L, Coppola R, De Feo V. Effect of essential oils on pathogenic bacteria. Pharmaceuticals. 2013;6(12):1451-1474.

16. Pasqua RDi, De Feo V, Villani F, Mauriello G. In vitro antimicrobial activity of essential oils from Mediterranean Apiaceae, Verbenaceae and Lamiaceae against foodborne pathogens and spoilage bacteria. Annals of Microbiology. 2005; 55(2):139-143.

17. Pourghanbari G, Nili H, Moattari A, Mohammadi A, Iraji A. Antiviral activity of the oseltamivir and Melissa officinalis L. essential oil against avian influenza A virus (H9N2). Virus Disease. 2016;27(2):170-178.

18. Karmakar S, Khare RS, Ojha S, Kundu K, Kundu S. Development of Probiotic Candidate in Combination with Essential Oils from Medicinal Plant and Their Effect on Enteric Pathogens: A Review. Gastroenterol. Res. Pract. 2012; 2012:Article ID 457150.

19. Turgis M, Dang VK, Dupont C, Lacroix M. Combined antimicrobial effect of essential oils and bacteriocins against foodborne pathogens and food spoilage bacteria. Food Research International. 2012; 48(2):696-702.

20. Yang C, Chowdhury M, Huo Y, Gong J. Phytogenic compounds as alternatives to in-feed antibiotics: potentials and challenges in application. Pathogens. 2015; 4(1):137-156.

Стаття надійшла до редакції 08.09.2021 р. 